University of Rhode Island

DigitalCommons@URI

$1-2003$

\title{
A Model for Integrating the Public into Scientific Research
}

Claudia Barreto

David E. Fastovsky

University of Rhode Island, defastov@uri.edu

Peter M. Sheehan

Follow this and additional works at: https://digitalcommons.uri.edu/geo_facpubs

Terms of Use

All rights reserved under copyright.

\section{Citation/Publisher Attribution}

Barreto, C., Fastovsky, D. E., \& Sheehan, P. M.(2003). "A Model for Integrating the Public into Scientific Research," Journal of Geoscience Education, 51(1), 71-75. doi: 10.5408/1089-9995-51.1.71

Available at: https://doi.org/10.5408/1089-9995-51.1.71

This Article is brought to you for free and open access by the Geosciences at DigitalCommons@URI. It has been accepted for inclusion in Geosciences Faculty Publications by an authorized administrator of DigitalCommons@URI.For more information, please contact digitalcommons-group@uri.edu. 


\title{
A MODEL FOR INTEGRATING THE PUBLIC INTO SCIENTIFIC RESEARCH
}

\author{
Claudia Barreto \\ Department of Biological Sciences, University of Wisconsin Milwaukee, Milwaukee, WI 53201, \\ barr@uwm.edu \\ David E. Fastovsky Department of Geosciences, University of Rhode Island, Kingston, RI 02881, \\ dfa3228u@postoffice.uri.edu \\ Peter M. Sheehan Geology Section, Milwaukee Public Museum, 800 West Wells St., Milwaukee, WI 53233, \\ sheehan@uwm.edu
}

\begin{abstract}
Science progresses whenever new ways of explaining natural phenomena are revealed. New ideas can only be put to use after the results and significance of research have been brought to the attention of both the scientific and lay communities. The Milwaukee Public Museum Dig-A-Dinosaur Program is a model for scientists who want to conduct research as well as engage and educate the public in their field of study. An array of rewards is derived from including amateurs as members of a research team. Such collaborations strongly increase interest in and comprehension of science as a process. Active participation in scientific investigations promotes one's ability to grasp the logic employed to construct scientific knowledge. Derivative to this, people who experience research enthusiastically share what they learn with diverse audiences. Moreover, the productivity of the scientist can be significantly increased, as exemplified in an extensive paleoecological research project conducted by the authors. In retrospect, the project provided an educational experience for the volunteers that should have been formalized. It would certainly be appropriate to earn college credit based on participation and formalization would validate this learning experience.
\end{abstract}

Key words: Education (general); education - assessment; education - field based; education - paleontology; science (general); stratigraphy; historical geology; paleoecology.

\section{INTRODUCTION}

One of the most significant responsibilities of a professional scientist is to clearly communicate the goals, consequences and logic of their research to the public. If individuals and society are going to effectively evaluate and address science-related issues, scientific literacy is mandatory. Some scientists bemoan the ignorance of the populace and/ or the shortfalls of K-12 science education. However, if we are sincerely concerned with upgrading science education, then we are obligated to willingly take part in diverse outreach forums.

The Milwaukee Public Museum Dig-A-Dinosaur (DAD) Program can serve as a model for scientists to replicate, adapt and embellish in order to engage the public in their research. Moreover, partnerships between scientists and the public, as exemplified by $\mathrm{DAD}$, slay a flock of proverbial birds (feathered dinosaurs) with one stone.
- Such programs serve as dynamic education vehicles for the general public by involving them in the process of scientific discovery.

- Professional/amateur collaborations are wellsprings for exhibits, articles and presentations that promote science literacy at a variety of levels.

- Utilization of volunteers in data collection, collections management, and public relations supports scientific research.

\section{INTEGRATING VOLUNTEERS INTO SCIENTIFIC RESEARCH}

Project Description - In 1986, Milwaukee Public Museum (MPM) paleontologists and associated scientists initiated an ambitious research project to study the controversial Cretaceous-Tertiary extinction event (Sheehan and others, 1991). Although it was recognized that many organisms went extinct at the close of the Mesozoic Era, the scarcity of terrestrial fossils made it difficult to determine if the extinction of dinosaurs was abrupt or gradual. To test these opposing hypotheses on the tempo of a pivotal event in the history of life, a unique experimental design was formulated. The experiment necessitated collection of a statistically meaningful sample of in-place fossils (in this case bones situated where they were originally deposited) that would enable us to determine ecological diversity patterns at the end of the Cretaceous. The study areas were in the Hell Creek Formation in Montana and North Dakota. This unit of sedimentary rocks was deposited by a system of rivers during the final 2.1 million years of the Cretaceous and is world-famous for preserving dinosaur fossils (Archibald and others, 1992; Baadsgaard and others, 1980; Fastovsky, 1987; Lupton and others, 1980; Sloan and others 1986; Smit and others, 1984; White and others, 1998).

In the field, precise information (geographical, geological and paleontological) had to be documented. Figure 1 is a sample of 2 of the data collection sheets used in the field. We had to consider the various ways in which fossils were deposited to accurately determine ecological diversity over late Cretaceous time because a true picture of ecological phenomena can be muddied by sedimentological differences among fossil deposits. It was critical to restrict comparisons over time solely to those fossils deposited under the same sedimentary conditions. Thus the experiment was designed to assess changes in the numbers and kinds of dinosaurs deposited within each distinct sedimentological environment (facies) from the bottom (oldest beds) to the top of the Hell Creek Formation. Such an ambitious and time consuming data collection scheme demanded either a lot of time or a lot of data collectors. 

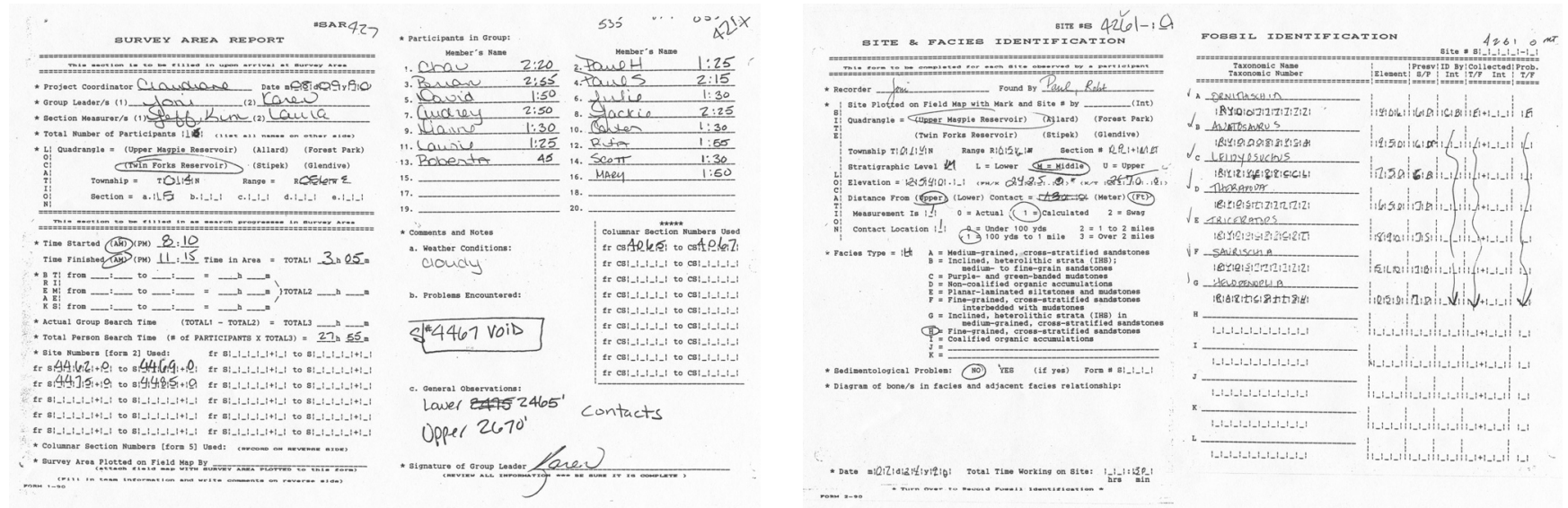

Figure 1. Two of the forms used to collect data (both sides of each foram are shown side-byside). A. Survey Area Reports include geographic information, person hours spent on prospecting the area and references to the other forms on which data was collected for this area. B. Each time a fossil was located and determined to be in place, a Site \& Facies Identification form was completed. This required recording specific geologic information as well as a list of the fossils. The forms were designed to facilitate entry into the data-base.

Recruitment of Participants - To generate the required database, volunteer field crews were summoned to action. This was possible due to the popular MPM Dig-A Dinosaur (DAD) Program. A historical account of this high profile volunteer program is presented below. The main avenue for marketing the expedition was through publications generated by the Friends of the Milwaukee Public Museum, Inc. In addition, informational brochures, designed by project scientists, were distributed at the museum, local universities and area K-12 schools (with which we had established alliances) because we felt the program would be particularly appealing to teachers. A number of recruits who signed on in subsequent field seasons heard about the program from past volunteers and repeat volunteers often brought along new friends and/or family members.

People responding to our call for volunteers were sent a packet of information describing the research project, their responsibilities as field crew members and an application form. Applicant requirements included:

- Minimum age of 15 years and participants under 18 years had to be accompanied by an adult;

- Interest in scientific research;

- Current health insurance coverage;

- Transportation to and from the study area (we did arrange to pick up and drop off volunteers who chose to travel by Amtrak).

- Permission from primary physician to take part in physically demanding exercise in a desert environment;

- Signing a waver exempting the museum from legal responsibility for accidents incurred during participation.

Each field crew consisted of 25 volunteers. The groups contained families, couples and singles. Most groups included several:

- retirees

- high school and college students

- high school teachers
In the first field season we employed three crews (in three consecutive 2-week sessions). In the remaining two field seasons we ran two 2-week sessions. In all, over 150 volunteers participated in the three years required to complete the fieldwork. Participants had wide ranging educational, career and outdoor experience backgrounds. Although most participants were from Wisconsin, we did have a few from out of state and one from Australia. Two common attributes of participants were a profound interest in paleontology and in having an opportunity to be members of a research team.

The Role of Participants - Unlike previous DAD expeditions in which the goals were primarily to locate and recover fossils suitable for museum exhibits, the extinction project volunteers had to be thoroughly educated so they could aptly fulfill their duties in the data collection process. Participants from all groups (2-3 field crews of 25 persons each) attended four half-day Saturday classes at the museum during the two months preceding the field season. Over and above assuring a thorough understanding of the research, in part our motive was to confirm their commitment to the project. To prepare recruits for participation, lessons were offered in: paleontology, sedimentology, extinction, the scientific method - in general and the specific methods necessary to amass valid data for the extinction research project - and fieldwork preparedness (including wilderness medicine). Before each class, volunteers were sent selected readings based on their suitability for introducing lesson topics to the lay person. Combined with lecture and discussion, the classes provided hands-on fossil and rock specimen examination.

The role of these carefully trained and supervised volunteer field crew members was to systematically search predetermined study areas in the Hell Creek Formation for all fossils, so that project scientists could record data on specimens in the context of the research objectives. In the field, volunteers, scientists and staff were spread out, search-party style. Volunteers were instructed to leave fossils they discovered undisturbed, marking them with a survey flag and immediately notifying a staff person. Subsequently, geologists and paleontologists would determine if fossils were indeed 
in-place (so the sedimentological context was not lost) and oversee accurate recording of data.

The Education of Participants - The theory that true learning comes from individual construction of knowledge is widely accepted by educators. Pedagogical research has demonstrated that the best way to learn science is to do science (Burgener, 2001; Caparo, 2001; Gagnon and Collay, 2001). "Until you personally experience something, it's difficult to take the leap of faith that what something someone is trying to teach you is true, real, accurate, or will have any importance in your life" (Barton, 2001). DAD fieldwork participants learned (through hands-on experience) principles of paleontology and geology and, more significantly, how to test scientific hypotheses to advance scientific knowledge (in this case furthering our understanding of a prominent extinction event). The teaching arena and learning environment in this "classroom without walls" were ideal. Paleontology and geology are disciplines with temporal and spatial components and accordingly making personal observations in the field significantly facilitates learning. The low student-to-teacher ratio allowed us to address questions, clarify misconceptions and follow each individual's progress as they proceeded to apply information from readings and classroom discussions out in the field.

Although we did not "grade" our volunteers, this would have been feasible so that volunteers could have earned college and/or continuing education credits. In fact, we advocate developing such partnerships into courses. For example, participation easily fulfils fits the bill for a service-learning course (Canada and Speck, 2001; Gibson, 2001). As one component of the assessment of participant leaning, we suggest requiring each student to keep a scientific notebook of her or his experiences (protocols, observations, questions, etc.) and write a referenced report on some aspect of the project. Educators would be required to create lesson plans based on research. In addition, the one-on-one interactions between scientists and participants allow for authentic, performance-based assessment of each individual's learning (Ediger, 2001; Pilcher, 2001) in the field. We did feel confident that we could write meaningful letters of recommendation for participants who requested them.

Although the participants' designated role was to serve as many extra eyes and feet for the paleontologists, a number chose to attend our nightly meetings during which the staff reflected on the day's activities, reviewed data and tried to resolve problems. These sessions also involved checking the day's data sheets, filling in information and noting sites we would need to reexamine. Completing data forms is tedious work, but participants cheerfully volunteered to act as scribes whenever we were able to resolve incomplete data records. Their meticulous work and supportive involvement beyond field work were invaluable to the progress of the research.

A tried and true measure of course and curricular effectiveness is by the capability to recruit and retain students. Volunteers have described their DAD participation as a powerful and rewarding educational experience. This was manifest in the many re-enlistees for fieldwork (usually comprising 10-15\% of future field crews) as well as the cadre (approximately 25\%) who remained active in project organization, specimen preparation and/or the development of experiencebased outreach endeavors.

A further testament to the DAD participant learning process is seen in their proficiency and eagerness to share their knowledge. Repeat volunteers proved to be effective mentors for first-timers; in fact, several were recruited as staff in subsequent field seasons. Functions these veterans served were broad based, from guiding participants in the field to becoming camp directors who coordinated the non-scientific aspects of housing, feeding and entertaining large field crews.

Impacts on Participants - DAD launched a number of college majors and professional careers. Several of the high school students decided to study the geosciences in college. Students from UWM, the University of Rhode Island and Marquette University, (working with project scientists) have completed internships, undergraduate independent study projects and graduate theses based on their DAD fieldwork participation and/or analysis of data collected by DAD field crews. In addition, teachers who signed on as volunteers continued to collaborate with us to create instructional presentations and teaching collections for use in their classrooms. Serving as a unique continuing education opportunity for teachers, DAD participation motivated the development of innovative science lessons in which the teachers were well versed and eager to infect their students with the excitement of scientific discovery.

\section{THE VALUE OF VOLUNTEERS IN SUPPORTING RESEARCH}

DAD volunteers enabled compilation of a unique, field-based record documenting the composition and structure of ecological communities over the final 2.1 million years of the "Age of Dinosaurs." Accumulation of the extensive database within three field seasons necessitated large field crews. It would have been unfeasible (logistically and cost-wise) to run a project employing thirty professionals working together for six weeks, for three summers. The climate of the DAD program welcomed participants as members of a scientific team and gave them an opportunity to contribute to paleontological research. This can be likened to service-learning, a practice that gives individuals on the job professional development and a bona fide appreciation of the nature of a profession (Canada and others, 2001; Gibson and others, 2001). Active involvement at this level affords a complete and realistic view of the processes and demands of research in the geosciences.

Although provided with background information, the inexperience of the volunteers proved to be advantageous in that it shielded data collection against preconceived biases. For example, when you accompany professional vertebrate paleontologists in the field, each seems to have an eye out for particular critters. Some excel at finding tiny elements, some have radar for particular taxa, some have a gift for finding juveniles while even others are human pendulum dowsers who locate complete skeletons. Furthermore, most paleontologists have opinions on momentous events such as the K/T extinction that can skew our attitude when looking for fossils in certain places. The volunteers scoured the outcrops hoping to find fossils anywhere. By the end of the three-year project, 15,000 hours of 
fieldwork was logged and data had been compiled on thousands of fossils. The database has been ideal for diverse analyses that have resulted in presentations at professional conferences and peer-reviewed reports that have provided key insights into this pivotal event in the evolutionary history of life.

Volunteers were also critical to funding this research project. DAD participants paid a fee (approximately $\$ 2,000$ per person) and provided their own transportation to and from the field-camp. Therefore, our budget did not include salary, transportation and room and board costs normally required to support a field crew. The scope of the survey would have been too costly to complete otherwise.

Added perks that arise from partnering with volunteers include unflagging loyalty, moral support and acquisition of ambassadors to spread the word that scientific research can be inclusive (with niches for everyone), fun, challenging and offers valuable learning opportunities. Many volunteers continued their service to our research, donating their time and talent to assorted curatorial duties at the museum. At the end of each demanding two-week field session, we were overwhelmed by the gratitude of departing participants and the enthusiasm of new arrivals. The varied personalities and genuine interest in our research served to boost our morale. These people were on vacation and were having then time of their lives, cheerfully taking on what we feared might seem like drudge work in a remote and rugged desert with thorny plants, snakes and scorpions.

\section{HISTORY OF THE DIG-A-DINOSAUR PROGRAM}

The Early Years - The Milwaukee Public Museum Dig-A-Dinosaur Program was originally conceived to facilitate construction a new geology exhibit hall, "The Third Planet." Constrained by a tight budget, yet determined to produce notably captivating and informative earth science lessons, museum curators Robert M. West and Diane L. Gabriel decided to recruit volunteers to help recover fossils for some of the exhibits they had planned. The performance and enthusiasm of the volunteer field crews were remarkable. The monetary value of the time and effort volunteers contributed to the quality of this world-class hall is inestimable. Moreover, their distinguished accomplishments precipitated an invitation to have DAD field crews participate in a survey of Dinosaur National Monument to locate new fossil localities, under the direction of Daniel J. Chure. This was the inaugural melding of DAD field crews in a project in which documentation of scientific data would be crucial.

A Cascade of Educational Outcomes - The original payoff of using DAD volunteers was in collecting specimens for exhibit in the MPM geology hall. Today, visitors to "The Third Planet" are lured into a wondrously edifying milieu. The centerpiece of the hall is a series of exhibits on life in North America during the Cretaceous. This aggregation, which features specimens (including fossils discovered by DAD field crews) along side awesome dioramas derived from this evidence, has attracted international acclaim. The displays illustrate how raw data is used to reconstruct past life, thereby fostering insight into the scientific method. College students enrolled in evolution courses at the University of Wisconsin Milwaukee, are sent on urban field trips to "The Third Planet" to answer questions about the evidence, patterns and processes of evolution. Invariably, they return exhilarated and enriched from their immersion in the wealth of informational resources the hall provides. Museum curators are inclined to be effective communicators and educators because their job requires interactions with audiences of all ages and backgrounds, and they understand how diverse activities and media can accommodate a broad spectrum of learners.

In public relations and educational outreach terms, the DAD program was a huge success. Reports for the general public on research conducted using DAD field crews included articles (Sheehan, '94) and radio programs. Paul Hayes, science editor of The Milwaukee Journal Sentinel, who was a DAD participant for two field seasons, provided compelling newspaper coverage. Many other DAD field-crew members also became active in educating the public through a range of outlets, including becoming MPM Docents (volunteers specially educated to conduct public tours), integrating their DAD experiences into formal classroom activities and delivering presentations to community organizations.

Involvement in DAD by Dr. Mary Gruhl, Director of the University of Wisconsin Milwaukee Center for Science Education (CSE), catalyzed development of paleoecology lessons for K-12 students, which meet national science and math standards and integrate math and science disciplines (www.uwm.edu/Dept/CSE/ index.html). The CSE paleoecology lessons leverage the universal allure of dinosaurs to engage diverse learners in math, science and technology. These modules (taught at the CSE or transported to area schools via the Science Van) are the result of Dr. Gruhl's ongoing collaborations with DAD researchers.

\section{CONCLUSIONS}

An abundance of mutually beneficial outcomes sprang from this extraordinary symbiotic relationship, many of which were only truly appreciated in retrospect. Among the most important is the model DAD provides for similar research alliances. Through DAD it was demonstrated that the public could be effectively integrated into research. When afforded appropriate instruction and supervision amateurs can help collect information suitable for scientific analyses.

While our primary purpose was to conduct an extensive survey for the extinction research project, the education of the volunteers and the myriad derivative avenues of outreach and dissemination were equally worthy outcomes. If scientists earnestly wish to promote science literacy, we must realize our obligation to share all aspects of scientific discovery with the public. The results and the rewards just might surpass your expectations.

\section{ACKNOWLEDGMENTS}

We wish to thank all of our DAD volunteers. Terry and Mary Kohler provided generous support for DAD research. Pamela Primeggia graciously edited the first draft. 


\section{REFERENCES CITED}

Archibald, J.D., Dingus, L., Butler, R.F., Lindsay, E.H. and Clemens, W.A. 1982, Upper Cretaceous- Paleocene biostratigraphy and magneto-stratigraphy, Hell Creek and Tullock formations, northeastern Montana ( USA), Geology, v. 10, p. 153-159.

Barton, M.H., 2001, Coming full circle: teaching for beyond the classroom, in Stephenson, F., editor, Extraordinary Teachers: Kansas City, Andrews McMeel Publishing, p. 217.

Baadsgaard, H. and Lerbekmo, J.F., 1980, A Rb-Sr age for the Cretaceous- Tertiary boundary ( $Z$ coal), Hell Creek, Montana, Canadian Journal of Earth Sciences, v. 17, p. 671-673.

Burgener, S.C., 2001, Scholarship of practice for a practice profession, Journal of Professional Nursing, v. 17, p.46-54.

Canada, M. and Speck, B.W., editors, 2001, Developing and implementing service-learning programs, San Francisco, Jossey-Bass, 103 p.

Capraro, M.M., 2001, Defining constructivism: Its influence on the problem solving skills of students, Paper presented at the Annual Meeting of the Southwest Educational Research Association (New Orleans, LA, February 1-3, 2001), 28 p.

Ediger, M. 2001, Assessment: A teacher's guide: Kirksville, Simpson Pub. Co. 6 p.

Fastovsky, D.E., 1987, Paleoenvironments of vertebrate-bearing strata during the CretaceousPaleogene transition, eastern Montana and western North Dakota (USA), Palaios, v. 2, p. 282-295.

Gagnon, G.W., Jr. and Collay, M., 2001, Designing for Learning: Six Elements in Constructivist Classrooms: Thousand Oaks, Corwin Press, Inc., A Sage Publications Co. 167 p.

Gibson, M.K., Kostecki, E.M. and Lucas, M.K., 2001, Instituting principles of best practice for servicelearning in the communication curriculum, Southern Communication Journal, v. 66, p. 187-201.

Lupton, C. , Gabriel, D., West, R.M., 1980, Paleobiology and depositional setting of a Late Cretaceous vertebrate locality, Hell Creek Formation, McCone County, Montana: University of Wyoming, Laramie, Contributions to Geology, v. 18, p. 117-126.

Pilcher, J.K., 2001, The standards and integrating instructional and assessment practices: Paper presented at the Annual Meeting of the American Association of Colleges for Teacher Education (53rd, Dallas, TX, March 1-4, 2001), 10 p.

Sheehan, P.M. 1994, The extinction of the dinosaurs: in Rosenberg, G.D. and Wolberg, D.L., editors, Dino Fest: Proceedings of a Conference for the General Public, The Paleontological Society. Special Paper no. 7, p. 411-423.

Sheehan, P.M. and Fastovsky, D.E., 1992, Major extinctions of land-dwelling vertebrates at the Cretaceous-Tertiary boundary, eastern Montana, Geology, v. 20, p. 556-560.

Sheehan, P.M., Fastovsky, D.E., Barreto C. and Hoffmann, R.G., 2000., Dinosaur abundance was not declining in a "3 $\mathrm{m}$ gap" at the top of the Hell Creek Formation, Montana and North Dakota, Geology, v. 28, p. 523-526.

Sheehan, P.M., Fastovsky, D.E., Hoffman, R.G., Barreto, C.B. and Gabriel, D.L., 1991, Sudden extinction of the dinosaurs: latest Cretaceous, Upper Great Plains, USA, Science, v. 254, p 835-839.

Sloan, R.E. , Rigby, J.K. Jr., Van Valen, L.M. and Gabriel, D., 1986, Gradual dinosaur extinction and simultaneous ungulate radiation in the Hell Creek Formation (USA), Science, v. 232, p. 629-633.

Smit, J. and Van Der Kaars, S., 1984, Terminal Cretaceous extinctions in the Hell Creek area, Montana: compatible with catastrophic extinction, Science: $v$. 223, p. 1177-1179.

White, P.D., Fastovsky, D.E. and Sheehan, P.M., 1998, Taphonomy and suggested structure of the dinosaurian assemblage of the Hell Creek Formation (Maastrichtian), eastern Montana and western North Dakota: Palaios, v. 13, p. 41-51.

Williams, M.E., 1994, Catastrophic versus noncatastrophic extinction of the dinosaurs: testing, falsifiability, and the burden of proof, Journal of Paleontology, v. 8, p. 183-190. 